\title{
Fabled Futures: Migration and Mobility \\ for Samoans in American Football
}

\author{
Fa'anofo Lisaclaire (Lisa) Uperesa
}

\section{The “Legend”}

In October 2009, I attended a large banquet dinner in honor of the University of Montana Hall of Fame inductees, members of the I969 and I970 undefeated championship football teams. After the dinner was over, I sat at a table with my father, Tu'ufuli, and a few of his former teammates as they were catching up on news and reminiscing. My father is in his mid-sixties, a retired athlete and educator, and he lives in American Sāmoa. Born on the island of Tutuila, he played football through to the professional ranks in the United States and Canada, and over the years he has traveled extensively as an athlete, coach, and trainer.

As we sat talking, suddenly an attractive, middle-aged woman walked up to us, brimming with emotion and excitement. "Is this Tu'ufuli?" she asked as she reached out, clasping his hand in hers and holding on for a moment. "I just wanted to shake your hand-We've never met but I was a cheerleader, cheering you on, and you were just legendary! Legendary!" she exclaimed. He smiled, graciously remarked how nice it was to meet her, and introduced us. With earnest excitement she told me, "Tu'ufuli was a legend on campus. You ask about professors on campus and people would say, 'Who?' But Tu'ufuli everyone knew. 'Tu'ufuli! Tu'ufuli! Tu'ufuli!' [He] was just legendary." As she walked away, I was struck by the immense satisfaction she seemed to get from greeting him and recounting the memory of his presence on campus. Although I sensed the brief interaction made him slightly uncomfortable, over the course of the weekend I saw that he enjoyed the respect many accorded him and that he is proud of his football accomplishments.

On the following day, the University of Montana Grizzlies hosted the Eastern Washington Eagles. As we crossed the footbridge toward the tail-

The Contemporary Pacific, Volume 26, Number 2, 28I-30I

(C) 2014 by University of Hawai'i Press 


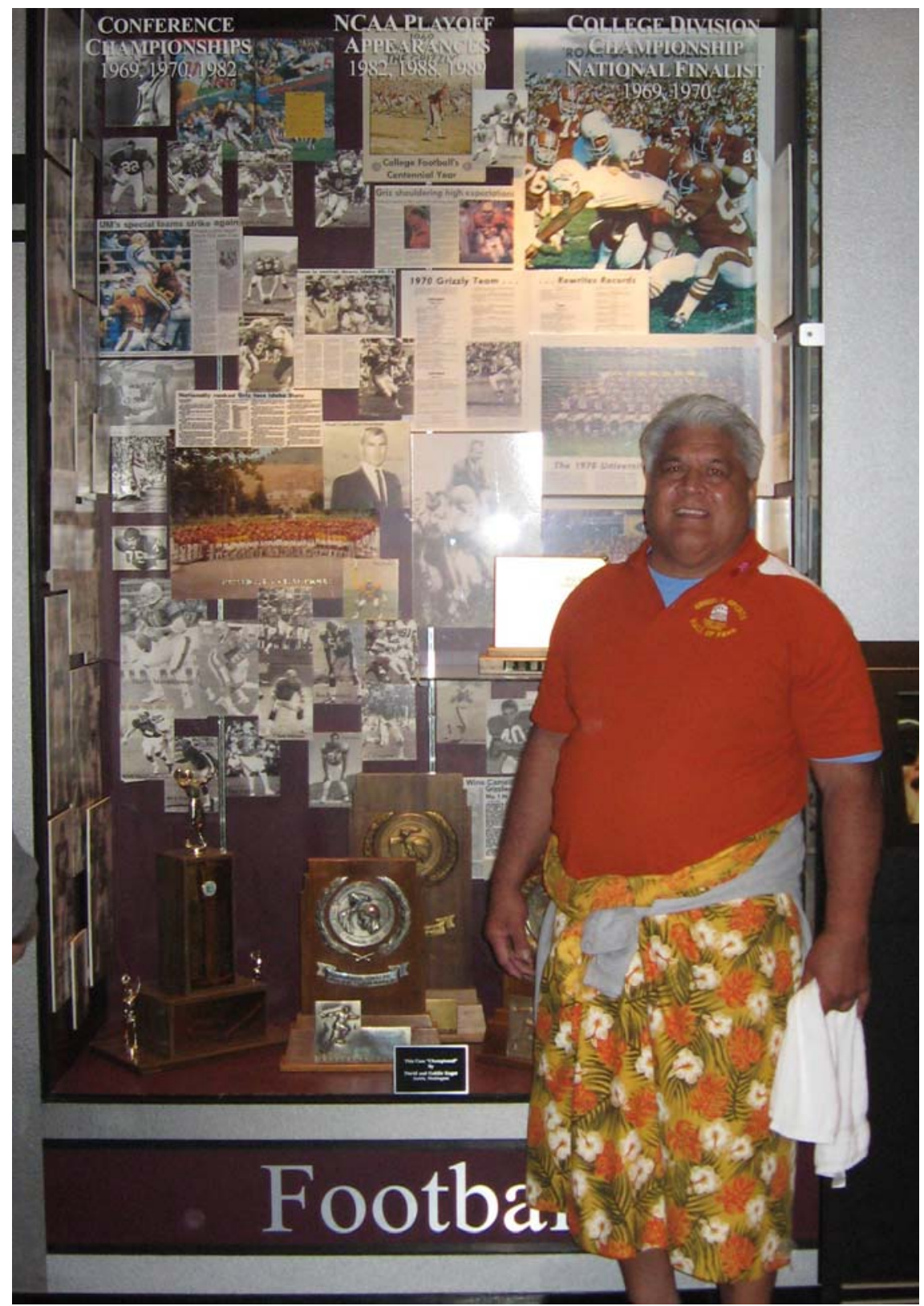

Figure I Tu'ufuli K Uperesa, Cocaptain, University of Montana Grizzlies, and inductee into the I 969 and I 970 University of Montana Hall of Fame Football Team, October 2009. Photo by author. 
gate area and stadium, I saw my father wipe the sweat from his brow as he walked over to join his old friends and teammates-a sign of the effort required to move the weight of his six-foot-four frame, which carried the evidence of the slow pace and rich eating of daily life in Sāmoa, packed on top of muscle hardened by years of dedicated sport training. His hair was a shock of white, and his deliberate steps betrayed repeated knee injuries, shoulder surgery, bodily destruction from battles on the offensive line, and, finally, acute arthritis and gout. Still, he walked with a perceptible pep in his step, buoyed by the ebullience of the crowd and the excitement of the occasion. He was the last to enter the stadium, yet, perhaps in a nod to his former status as cocaptain, his teammates insisted that he lead them onto the field.

As they entered, the crowd of more than 20,000 was on its feet with a standing ovation, honoring the inductees. Watching from the stands I wondered, how does a boy born in Tutuila, American Sāmoa, come to be inducted into the Hall of Fame in Big Sky Country? In this article I ask: What motivates and enables such a journey? How does that journey shed light on changing conditions of possibility for Samoan movement and mobility as linked to the transnational sport industry and migrant pathways? I explore the layered and complex motivations for football participation as shaped by prospective forms of capital, transnational sporting institutions, and historical contingency.

\section{New Voyages: Expanding Routes of Transnational Mobility}

Gridiron football has become an important part of life in Samoan communities in the islands and in linked urban and suburban areas of the United States. In American Sāmoa, the sport's visibility and vibrancy owes much to its connection to the changing market of the American football industry, which for several decades now has opened new opportunities for Samoan youth at the college level. Over this time period, Polynesian players have also been racialized in ways that help them enter this line of work but restrict them from others: they are stereotyped as genetically gifted with size, girth, and quickness suitable for football, as well as with a violent impulse that can be channeled into success on the field by virtue of their respect for authority, instilled by discipline and socialization in hierarchical Samoan society (see also Henderson 20II). In my current research, I argue that increased Samoan participation and success in American foot- 
ball is a complex crystallization of imperial legacies, restricted economic opportunities, and socioeconomic inequality, as well as Samoan community histories and cultural sensibilities that shape approaches to duties, obligation, and status in various locations (see also Uperesa 2010 and forthcoming). In this article I share my father's story because it is both exceptional and exemplary: taken together with others' experiences, it illustrates the recent history of Samoan geographic and socioeconomic mobility in American football and how important geopolitical and transnational shifts have provided the conditions of opportunity for contemporary Samoan movement and mobility through sport. Focused on history, economy, and transformed visions of the future, this article speaks to a critical genealogy of football in (American) Sāmoa and of Samoans in American football.

For many, playing football is a response to limited structures of opportunity both in Sāmoa and in the United States, ${ }^{1}$ although each context is distinct. I argue that the sport's rise in Samoan communities is closely tied to the recognition and forms of capital it offers players, families, and wider communities: economic capital in the form of college scholarships, professional salaries, and endorsements; cultural or symbolic capital in the form of prestige, educational credentials, and expertise; and social capital in the form of expanded social and professional networks (Bourdieu I984, I986). Capital, in Pierre Bourdieu's articulation, is "accumulated labor" in a "materialized form" that is appropriated by people or groups of people. How the different types of capital are distributed in a society reveals the "immanent structure of the social world, i.e., the set of constraints, inscribed in the very reality of that world, which governs its functioning in a durable way, determining the chances of success for practices" (Bourdieu I986, 24 I-242). In this way, social privilege, access, and inequality shape one's future possibilities.

While Bourdieu's theory of capital emerges from a sedimented set of assumptions and preoccupations not fully applicable to the American Sāmoa context, ${ }^{2}$ it still remains a useful lens through which to view the dreams of upward mobility and the themes of opportunity and college access shared with me by many players, their families, and their communities. However, we must also attend to the limits of the model of capital, weighing, for instance, the importance of cultural sensibilities and how they shape the players' and communities' engagement with the sport beyond market principles or the logic of capitalist accumulation. For example, widespread participation testifies to the importance of genealogy 
and family relations in shaping whether boys play football. Some have passion for the game, some focus on the team brotherhood, and some play to carry on a family legacy or to fulfill others' expectations. In the context of Sāmoa-while it is clear that the cash economy structures much of daily life-money and wealth are not the only, and perhaps not even the most important, factors shaping what people do. This pushes us to examine how the material, social, and imaginative dimensions of football are woven together in ways that draw in young players and their communities, in order to understand how football-related migration has emerged as an important gendered path of transnational movement.

\section{Layered Histories and the "Polynesian Pipeline"}

Born in I948, a fraternal twin with two older siblings, Tu'ufuli (by his own description) grew up poor. Like many other later migrants from Sāmoa, as a child he followed the path of Fitafita relatives to Hawaici $i{ }^{3}$ there he was part of a growing Samoan community. Since its establishment in American Sāmoa in I 899, the United States military has been a significant source of transnational movement for many Samoans. As a source of wages, military benefits, prestige, and eventually, remittances, the US military has been and remains an important source of economic, social, and geographic mobility for Samoan people (see Fa'aleava 2003; Janes I990; Taylor 20I0). This is a legacy of US imperialism in the Pacific, the creation of a colonial political economy in the islands, and American Sāmoa's status as an unincorporated, unorganized territory of the United States (see Fa'aleava 2003; Uperesa, forthcoming). While in the latter decades of the twentieth century Samoan men moving across the Pacific were able to take advantage of other kinds of opportunities, such as jobs in manufacturing, in security, and as longshoremen, the military remained an important path of geographic and socioeconomic mobility (Franco I99I). Increasingly, however, sport has become a new field of labor for Samoan communities. ${ }^{4}$

Sport-related movement builds on earlier migration trends and patterns but is unique in some ways: it has media visibility unmatched by other occupations Samoans have entered, and it offers rewards that far exceed those associated with other migration routes, including a direct link to upward mobility via college degrees for particular sports in the American system. Like other transnational athletic migration streams from the twentieth century (see James I993), colonial hierarchies and legacies fundamentally shaped Samoan presence in American football. However, its 
efflorescence in recent decades can be linked to the increased globalization of elite-level sports since the late twentieth century (Maguire 1999; Miller and others 1999).

By most accounts, the so-called Polynesian Pipeline began with a trickle in the I930s and I940s with the "barefoot leagues" and the occasional Asian-Pacific recruit from Hawai'i to the continental United States. Over the next two and a half decades, there were other players of Pacific Islander (mostly Polynesian) descent scattered in the collegiate and professional ranks (see Franks 2000, 2009; Markham 2008; Tengan and Markham 2009). A member of the "Aiea High School graduating class of I966, Tu'ufuli was part of this incipient pipeline of sportsmen from Hawai'i to the US continent. ${ }^{5}$ Preempting the military route, he emerged as an athletic standout in Hawai'i at a time when football was a growing presence in American life. In these early years, when National Football League (NFL) Commissioner Pete Rozelle began a concerted effort to create the spectacle surrounding the Super Bowl (and professional football more generally), television and other media coverage expanded the attendance, participation, and viewership of football in the United States (Tanier 20I0; Vogan 20I4). By the time Tu'ufuli moved on to Wenatchee Junior College, football had grown far from its Ivy League roots. Programs of varying size and strength offered full athletic scholarships (adopted by the National Collegiate Athletic Association [NCAA] in 1957 as a method of standardizing subsidies and recruiting), and in the wake of the civil rights movement, the color line was breached with more regularity. ${ }^{6}$

The decade of the I970s marks a watershed in the consolidation of this pipeline in which Polynesian players were funneled to the US continent on football scholarships and across the continent from West Coast communities. A Sports Illustrated article from that time, "Shake 'em Out of the Coconut Trees," heralded the beginning of a new tide (Johnston I976). It pointed out that while Samoan players often hailed from Hawai'i and the US West Coast, they had previously been grouped with the more recognizable Polynesian ethnic group, Hawaiians. With the new critical mass of players at the collegiate and professional levels, Samoans were forcing recognition of a distinct ethnic and cultural identity through their success on the field, an important source of community pride. This time period also marks a nascent pathway of football-specific movement reaching back to Sāmoa and the beginning of a circuit that bypassed Hawai'i high schools. The 1976 article predicted a wave of scouting and recruiting direct to the Samoan islands that has only really materialized since the late I990s. In 
the interim, recruiting occurred largely by word of mouth and via personal contacts, a process in which Tu'ufuli was instrumental throughout the I980s. In films like Polynesian Power (Spear and Pennington 2004), we see a recent snapshot of the football landscape in the islands and the experience of two sons of Sāmoa, Isa'ako Sopoaga and Pisa Tinoisamoa, as they are drawn through these now-established pathways.

The Polynesian Pipeline flows in both directions, forming the basis of the movement of people, equipment, and expertise among the Samoan islands, Hawai'i, and the continental United States. Over the past ten years, Tutuila (American Sāmoa's largest island) has been the site of a number of football camps and combines that are designed to expand opportunities for Samoan student-athletes. These have been hosted by the American Samoa High School Athletics Association (AshsaA) and the Samoa Bowl Committee and sponsored by the AIgA Foundation, the All Poly Camp, the June Jones Foundation, and the Troy and Theodora Polamalu Foundation, among others. The local high schools have also benefited from equipment donations from current and former NFL players Domata Peko, Jonathan Fanene, Paul Soliai, Reagan Mauia, and Troy Polamalu, among others. A Hawai' $i$-based clearinghouse, the Pacific Islands Athletic Alliance (PIAA), and a recently disbanded local entity, Field House roo (FHIOO), have actively facilitated the recruitment of local student athletes by US colleges and universities. In 2010, 60 Minutes" "Football Island" profile highlighted the visibility of the "Sunday Samoans" seen weekly in NFL games and estimated that football players of Samoan descent are 56 times more likely to make it to the NFL than players of any other racial or ethnic group. ${ }^{7}$ This, combined with an even larger group of US- and islandborn Samoan players in the collegiate and professional ranks, has raised the sport's profile significantly. With this national attention, the dream of mobility, big money, and general hype around football is at an all-time high on Tutuila. Building on a long-standing migratory disposition and currents of transnational movement, the promise of sport looms large in the public imagination, even if its fulfillment remains elusive (Basch and others I994; Carter 2011).

\section{Transformative Possibilities}

The transnational nature of football migration is key to understanding the appeal of playing football, the rewards that accrue to successful players, and how these resources have continued to transform conditions of possibility (materially and ideologically) for young people in the islands. 
Don, one of the former players I interviewed, ${ }^{8}$ who played just as the game was getting organized in Tutuila in the late I960s and early I970s, described a scene in which football was in its infancy but catching the imagination of the young kids. It was a game that had to be consciously taught, since some of the coaches at that time had never played football themselves. According to Don, Albert "Al" Lolotai was the director of the athletic program at the time: he was the one who set up games, officiated, and began organizing the high school program. Lolotai gave each of the schools projectors and game film to study. Don noted that they also watched NFL Films, which, under the direction of Steve Sabol, are credited with creating the mystique of professional football.

It is unlikely that anyone could have predicted that not only would the enhanced media production of the sport of football inspire players (and later, some team owners) in the United States, but the glorification of the game would also strike a chord among Samoan youth in the late I960s and early I970s. Up until then, cricket and rugby had been the major sports-local fixtures well organized for different levels of competition (cricket was indigenized as kilikiti starting in the late $\mathrm{I} 800$, while rugby appears to have come much later, in the early I900s). Don remembered, "Every time it rained, all the kids would go down to the muddy malae [central village green] and play 50 on 50 , tackle." I asked him why they were taking up football when cricket and rugby were so entrenched, and he said, "They were broadcasting games, NFL and college, on KVZK-TV, so there was familiarity. With the pads it was full contact, which the kids loved. Plus you could go places with football, there was no future in rugby - with football you could go to school, make money, see places. NFL dreams." At a time when the sport was embarking on its own path of spectacle production, the visual medium of television captured the imagination of the youth as it transformed the coverage of the sport in American Sāmoa (up until then, sports news was accessed primarily through print media).

Aside from the college and professional games broadcast on cable and network television in American Sāmoa, the local games-once simulcast only on the radio-are now taped and replayed later in the weekend on the local broadcasting station. People who are not able to attend the games in person can view them on television. Still, while media exposure has played an important role in circulating images of the sport and in raising its profile both locally and in the United States (Dunnavant 2004), according to those I interviewed, so has personal experience of the excite- 
ment of the game, its connection to village and district rivalries, and its gendered iconography.

\section{"It Was Just Cool"}

In the late I960s and early I970s, the local game of football was just emerging in an organized context on the island and beginning to draw young players, although rugby was still dominant. In our interview, Don noted with amusement that at the time they called football a "woman's game" because you could wear pads, while rugby was a "tough man's game." According to him, for parents, football made more sense since there was no safety, no protection in rugby. By the late I970s and early I980s, rugby was still a tough sport, but football had far more cachet and was taking hold of minds and bodies as a new source of masculine status. One of the former players (Junior) who was active in the sport at that time related his early experiences with the rising popularity of football and its status as the "young man's game":

Well, rugby wasn't as popular here as [football] was then .... And I think also because, for us, it was cool . . . to wear the pads and the helmet. . . . Rugby, you just went out there and you were afraid you were going to get hurt. Someone would knock you out, you know ... then we could see there's cheerleaders ... and we were like, oh, man.... And at that time the booster clubs were really good.... And it was just cool.

Part of the excitement Junior described was being part of the upswing of interest and excitement around the sport, when booster clubs were active and fundraising for crisp new uniforms and equipment was on the rise. Football continued to grow in popularity and was drawing more people into its orbit, from some parents who followed the college or professional games, to young boys drawn to new performances of masculinity, and perhaps to a lesser extent, to girls who would be active on the sidelines as cheerleaders, also performing a new kind of femininity. Junior's experience illustrates some of the affective, social, and instrumental appeals of the sport. He tried out for the football team partly to see if he could parlay his athleticism into an opportunity to play in the United States. Remembering Don's remark as well, we know that, for many players, football was linked to the vague dream of success in football in the United States. As an American cultural form, it was enmeshed with imaginaries of Amelika as cosmopolitan, the source of "cool" for youth, the land of opportunity, and a fabled destination on the horizon. 


\section{New Fields of Possibility}

For many players from American Sāmoa, that path to Amelika is a circular one and at some point brings them back to the island. Returnees with some off-island success-like Tu'ufuli and others-were local icons, symbols of off-island movement, and active agents who both facilitated the disciplining of young Samoan bodies within the framework of sport and continued to promote a change whereby players and their families would increasingly see football as a ticket to college. The young men I spoke with who described football as "the only way to get off the rock, besides the military" are in many ways inheritors of this orientation to the importance of leaving the islands-not merely as part of a larger tradition of malaga (visiting, travel, movement; see Lilomaiava-Doktor 2009) but also for strategic opportunities for upward mobility today.

Since the late I970s, football has become a highly visible route to the United States; over the same time period, the American Samoan economy has become increasingly credentialed and dominated by a US-funded bureaucratic welfare state with a narrative of success that winds through American educational institutions. It is in this context that I saw a Scholastic Assessment Test (SAT) prep instructor at a local high school scold her students for not paying attention in class, asking if they want to end up working at the local canneries. ${ }^{9}$ Once quite seriously a symbol of "development," cannery work is now seen as a kind of failure, indexing a shift in ideas about success and "the good life" that have been transformed by transnational movement of various kinds over the course of the twentieth century.

In many ways, Tu'ufuli has been a strident proponent of movement off island for education. A number of interviewees revealed to me that they had either trained with him or had him as a coach. One described him as "like Vince Lombardi" in his ability to inspire and motivate players to perform physically and to have the confidence to see themselves succeeding off island. The social and cultural capital he accrued during his years playing college and professional football allowed him to mobilize coaching networks to place students at schools in the United States. At the same time, my mother, Kristin, tutored the players for the Test of English as a Foreign Language (TOEFL) and SAT exams and helped them sort through the paperwork required for college enrollment. Tu'ufuli and others have also been important to improving parental opinions of the sport and increasing support for children going away for school rather than staying to take care of family obligations on a daily basis. 
Alema, a former player, described these changes as representing a shift from an "old school mentality" to one in which (as a result of media coverage and personal contacts) parents now recognize football as an opportunity to go to college, get a degree, or even play professionally. This is an important shift he points to because in it we see parents and their children responding to an alternative vision of the future-one that is not only made possible by the transnational circulation of people and media images, but in turn is materialized by their own participation, substantiating the imagined possibility for themselves and serving as another narrative example for others.

The increasing support for football is not necessarily seen in direct investment in equipment, weight training programs, coach training (although these are all part of expatriate efforts to "give back" to the community), or in other policies of sport infrastructure building or increased allocations by the governor's office, local legislature, or Department of Education. What has changed is the amount of media coverage of local and USbased football; the increased presence of off-island coaches for camps and recruiting; the existence of highly anticipated games like the Samoa Bowl that draws players and coaches from the United States (and, in a recent iteration, from Australia) to play the American Sāmoa all-star team; the surge of representative teams traveling to international contests like the International Federation of American Football (IFAF) Under-I9 competitions; the assistance of more nongovernmental organizations providing donations and services to the island; as well as the ubiquity of support throughout the island during the season. This dynamic flow of people, goods, and ideas has transformed the local sportscape and linked it firmly to stateside nodes of sport activity (Appadurai I990; Carter 20I I). ${ }^{10}$

\section{Sports Mobility: A Dream, an Escape, an Opportunity}

Like those of many other young athletes, Tu'ufuli's accounts revealed different aspects of his experience in and attraction to sports. Excellence in athletics was a huge source of pride and accomplishment for a young boy, recently arrived in Hawai'i, who had been shuttled into special education classes because he couldn't speak English and was having trouble in school. Sports participation was also an important way to deal with and counter the racism he experienced both in Hawaici and on the US continent. In Hawai'i, Samoans have a long history of being concentrated in the poorest parts of the island and subjected to discrimination by the domi- 
nant socioeconomic groups (whites and Asians). Like other native Pacific Islanders in Hawai' $i$, stereotypes of Samoans as lazy, incompetent breeders and violent thugs have served to both limit their opportunities and explain their continued socioeconomic marginalization (see, eg, Merry 2000, I 28; Teaiwa 1995). Even recent decades of upward mobility for many Samoan families and high-profile success stories like former Honolulu Mayor Mufi Hannemann or current US congressional delegate Tulsi Gabbard have not dislodged these entrenched stereotypes.

With limited opportunities for Samoan migrants in Hawai'i in the I960s, Tu'ufuli used sports as a way up and out of the islands, as an alternative to opting out of the American system, becoming a beachboy, or returning to Sāmoa to farm the family land. As a "local boy made good" through sports, Tu'ufuli made a name for himself and his extended family and also represented Samoans positively within the wider community. His mastery of sport, first as a player and later as a coach and trainer, became his expertise and an important center of self-confidence and authority in relations with others. Although he was highly recruited out of high school, his low grades put him on the junior college path. At Wenatchee Junior College in Washington State, he drew fellow Samoan players from Hawai'i such as Leslie Kent, Jerry Lalau, and John and Pati Talalotu. Later, in Missoula, Montana, he never had to pay for anything and he lived well; all he had to do was play football. According to former teammates, this he did with fierce determination, and he left the University of Montana with its first undefeated season and its first division national championship. His life as a star college player brought a number of material rewards—a far cry from his difficult childhood in Sāmoa and Hawai'i.

\section{Returning Home}

After several years in the Canadian Football League and with the NFL's Philadelphia Eagles, in 1979 my father returned to American Sāmoa with my mother, my brother (age 5), and me (age 3) in order to care for our aging grandmother. Although football had been played on Tutuila for at least a decade before his return, he joined a critical mass of returning sportsmen and women who expanded sport outlets for youth. A number of individuals have been involved with developing football on the island over the past three decades, and many of them cycle among positions in administration (whether at the Department of Education or school level), teaching and coaching, or volunteering. ${ }^{11}$

Like other returnees who had short professional football careers (or 
didn't even make it past the initial draft or tryouts), Tu'ufuli did not return a rich man. Because he had not earned a great deal of money, he instead had to rely on the experience he gained and the expertise he developed during his years in college and playing pro football. With limited economic capital, he had to parlay social and cultural capital-specific knowledge about different sports, their training techniques, rules, and regulations, as well as his experience and classroom-based knowledge of the body (his bachelor's degree was in health and physical fitness)-into a career on Tutuila. As a head coach, he regularly posted undefeated seasons and sent scores of players off island for football and schooling. In his capacity as ASHSAA director, he managed equipment, refereed games, and organized a number of summer camps that featured NFL players (including Al and Falaniko Noga, Tiaina "Junior" Seau, and Keith Uperesa, among others). As a track and field coach, he escorted athletes to several Olympic Games, South Pacific Mini-Games, and Goodwill Games. In those roles he communicated to another generation the importance of competing, pushing oneself, adopting a strong work ethic, and maintaining discipline for success.

But Tu'ufuli's story is bittersweet. Today we understand NFL contracts to be highly lucrative, with deals ranging in the millions and a minimum annual rookie salary of $\$ 420,000$ as of $2014 .{ }^{12}$ The collective bargaining agreement between the players' union and owners established a minimum salary schedule according to experience in 1982 , but when Tu'ufuli played in the I970s, salaries were as low as $\$ 25,000$. Over the years, the contracts have skyrocketed, intensifying the promise of riches in the eyes of young hopefuls. In some ways this has changed the character of the sport, with the imperative to win and capitalization reaching ever-higher levels. While you could argue that players make much more money now than they did in the r970s (and certainly this is true), the NFL Players Association reports that the average career of an NFL player is three and a half years and that two years after retirement, 78 percent of NFL players have gone bankrupt or are under financial stress related to joblessness or divorce (Torre 2009). The possibility of accumulating economic capital is a good one, but these statistics urge us not to assume the durative nature of that accumulation.

Unlike some of his students, Tu'ufuli did not go into private business or pursue a political career. He remained in education, where there was little money to be had, and after a series of legal troubles and physical ailments, retired early. Barely past the age of sixty-five, Tu'ufuli is now on disability 
retirement and suffers from acute arthritis, gout, hypertension, and he recently underwent a knee replacement surgery to relieve pain associated with old football injuries. The days of running a mile or more a day in the heat of the afternoon on the island, playing golf, playing rugby, and rowing with his village 'aumaga (organization of untitled men) in the Flag Day races are long gone. Today, walking for any length of time is a challenge. No longer active in the local sports scene, his extensive service to the community and his role in the early stages of sport development on the island are a dim memory for some and a complete unknown to most of the new generation of players. As a University of Montana Hall of Fame inductee, he received recognition for his football accomplishments and revisited the site of the pinnacle of his football career. Now in his twilight years, he credits sports for providing a way to "make something" of himself, to "see the world," and to make a concrete contribution to the lives of young people on the island.

\section{Fabled Futures: Prestige, Recognition, AND Forms of Capital}

Transnational sport migration is a growing reality for people across the Pacific. But these routes have specific dynamics and histories, with both well-worn grooves and new offshoots that speak to regional and transnational geopolitical structures (Sassen I998) as well as to community histories and individual experience. The "fabled futures" once rooted in paradigms of modernization and development of years past are now woven into processes of globalization and gendered prospects for mobility represented by global industries such as American football (Uperesa 20I0).

I have argued that the size and opportunity structure of the football industrial complex attracts many young Samoan men to the game. For Tu'ufuli and many other players like him, football represented a viable avenue for accumulating economic capital (even though the potential payoff was meager by today's standards). But it was not all about money; the intense emotion and pride of accomplishment and representing one's family and community was a big draw to sport, as were other forms of cultural capital in the form of prestige, adulation, and connection to people invested in their performance on the field. In Samoan communities and beyond, the opportunity to "give back" once successful and establishedfulfilling the obligation and privilege of performing tautua (service, in this 
case expanded and transnationalized), has also been an important outcome for many.

Today, as players young and mature navigate the enmeshed logics and pathways connecting transnational sport industries and their home communities, they are driven to participate in processes of commodification to better position themselves to ascend the interlinked football sporting circuits. By undertaking a process of corporeal and subjective transformation, players enhance their worth and accumulate what I have elsewhere called "gridiron capital" within the context of football (Uperesa 20I0). The process of commodification is central to this path of transnational movement, and some view their own positioning with both cynicism and hope.

Tu'ufuli's story is hopeful in that sports participation and success allowed him to make a life for himself, care for ailing parents, and give his children opportunities not available to him growing up. It represents precisely the kinds of aspirations many young players and their families now have (except with more money at stake). His experience also provides a compelling example of how individual and community desires shape, and are shaped by, larger national, political, and economic projects of varying scales. Still, the bittersweet bodily sacrifice paid for the opportunities promised by these circuits interrupts the largely celebratory narrative reproduced in popular media stories.

As Thomas Carter has noted, this "veneer of celebrity actually obscures the processes of transnational capital, the structures of labour in a transnational industry, and how states are complicit in structuring this industry" (2OI I 6). In the late capitalist era of deterritorialized labor and capital (Deleuze and Guattari 2004 [1972]; Harvey I989), football migration is an elite form of migratory movement that nevertheless draws on the reserve labor of young Samoan men in an "underdeveloped" economy within a larger context of global inequality. The growth of these routes of prospective capital for American football is part of the broader history of US imperial expansion that has provided the preconditions for and continues to facilitate these paths of mobility. Realizing the unbridled potential of gridiron football requires migration and submission to racializing and commoditizing processes that sustain, rather than disrupt or challenge, national and global economic inequality. Given the recent revelations on risk and long-term injury, it is not yet clear what the effects of this exponentially expanded participation will be for the current generations and the communities (in the islands and the states) from which they come. 
What is clear is that there is little chance of this sporting movement dissipating. As pathways to future success are winnowed, dreams of fabled futures in sport loom ever larger in communities across the Pacific and beyond.

FA'AFETAI TELE LAVA to my father, Tu'ufuli Kalapu Uperesa, for sharing his story and giving permission for me to write about it; to my mother, Kristin Lee Nybo Uperesa, for many conversations about my father's and our family's journey; and to the others who took the time to talk with me. Thanks also to the three anonymous reviewers who provided careful and thoughtful comments on an earlier version of this article.

\section{Notes}

I According to the 2000 US Census, only I0.5 percent of Samoans enumerated in the United States had attained a bachelor's degree or higher, and I8.6 percent were in managerial or professional occupations, compared with 50.2 percent in sales, office, or service occupations and 30.5 percent in manufacturing, production, or construction occupations. The median family income for Samoans is among the lowest of Pacific Islanders in the United States, at \$4I, O9I, with the poverty rate among the highest at 20.2 percent (Harris and Jones 2005). These demographic statistics align with but are improved over the I980 US census, which found that the population as a whole was young and highly urbanized, with 27 percent of families below the federal poverty level (Franco I99I; Hayes and Levin 1983). As of the 2010 census, the average household income in American Sāmoa was $\$ 23,892$ (the minimum wage varies by industry from $\$ 2.13$ to $\$ 5.59$ per hour).

2 See LiPuma 1993 on culture and the specificity of French society in Bourdieu's theory of capital.

3 The Fitafita were Native Samoan enlistees in the US military (see Fa'aleava 2003).

4 I wish to mark that the focus on military service and sport as two primary paths for young Samoan men draws on and reproduces a new kind of masculine "warrior" ethos, although it is beyond the scope of this paper to analyze that in depth.

5 While there are structural and social dynamics specific to Hawai'i at this time, it is beyond the scope of this paper to detail them here. 
6 See Watterson 2000 and Dumas 2009 on histories of the growth of football in the continental United States.

7 See Pelley 20I0. While the data are unconfirmed, it does capture and convey the popular sentiment of opportunity for Samoans in football-something internalized and articulated by many young players today.

8 This analysis is based on archival and ethnographic research (including participant observation at football camps, combines, games, and practices; formal and informal interviews with current and former college and NFL players, current and former high school and college coaches, player family members, and key institutional contacts) in American Sāmoa and Hawai'i from 2007 to 2010 and from 2012 to the present. The initial research was made possible by fellowship support from Columbia University as well as the generous support of the Uperesa 'āiga and friends.

9 According to the 2007 US Department of Labor Economic Report, fish canning and processing employed 45 percent of the workers surveyed (at an average of $\$ 3.60$ per hour), while the American Samoa government employed 34 percent (up to $\$ 7.49$ per hour), and retailing, wholesaling, and warehousing employed 9 percent (US Department of Labor 2007).

Io With the reorganization of the American Samoan Rugby Union in 2010 and its admission as a full member in the International Rugby Board in 20I2, there have been new efforts to link local rugby to the professional circuits of mobility, movement, and capital of the international game, configured differently than the industry of American football. In time, these new efforts may challenge the dominance of the American game on Tutuila.

I I Included are Mac Ane, Li‘a Amisone, Luteri Fiso, Ed Imo, Peter Gurr, Lino Letuli, Ace Logo, Mataese Mataese, Tumua Matu'u, Fata and Vanu Moe, Pati Pati Jr, (Lealao) Melila and Moana Purcell, Oakland Salave'a, Samoa Samoa, Elia Savali, Time Sitala, Meki Solomona, Suaese "Pooch" Taase, and Francis Tuitele, among many others.

I 2 This is a base salary that does not include signing bonuses, roster bonuses, or any incentives built into the player contract. Minimum base salaries are set on a sliding scale by accrued years a player has played in the league.

\section{References}

Appadurai, Arjun

I990 Disjuncture and Difference in the Global Cultural Economy. Theory and Society 7:295-3 Io.

Basch, Linda G, Nina Glick Schiller, and Cristina Szanton-Blanc

I994 Nations Unbound: Transnational Projects, Postcolonial Predicaments, and Deterritorialized Nation-States. Langhorne, PA: Gordon and Breach. 
Bourdieu, Pierre

I984 Distinction: A Social Critique of the Judgement of Taste. London: Routledge \& Kegan Paul.

I986 The Forms of Capital. In The Sociology of Economic Life, edited by Mark Granovetter and Richard Swedbag, 24I-258. Boulder: Westview Press.

Carter, Thomas

20II In Foreign Fields: The Politics and Experiences of Transnational Sport Migration. New York: Pluto Press.

Deleuze, Gilles, and Felix Guattari

2004 Anti-Oedipus. Translated from the French by Robert Hurley, Mark Seem, and Helen R Lane. London: Continuum. First published in I972 as L'Anti-Oedipe.

Dumas, Lane

2009 Integrating the Gridiron: Black Civil Rights and American College Football. Rutgers, NJ: Rutgers University Press.

Dunnavant, Keith

2004 The Fifty-Year Seduction: How Television Manipulated College Football, from the Birth of the Modern NCAA to the Creation of the BCS. New York: St. Martin's Press.

Fa'aleava, Toeutu

2003 Fitafita: Samoan Landsmen in the United States Navy, I900-I95I. $\mathrm{PhD}$ dissertation in ethnic studies, University of California, Berkeley.

Franco, Robert W

I99I Samoan Perceptions of Work: Moving Up and Moving Around. New York: AMs Press.

Franks, Joel

2000 Crossing Sidelines, Crossing Cultures: Sport and Asian Pacific American Cultural Citizenship. Lanham, MD: University Press of America.

2009 Pacific Islanders and American Football: Hula Hula Honeys, Throwin' Samoans, and the Rock. The International Journal of the History of Sport I 6:2397-24 I I.

Harris, Phillip M, and Nicholas A Jones

2005 We the People: Pacific Islanders in the United States. Census 2000 Special Report, CENSR-26, August. Washington, DC: US Census Bureau. http://www.census.gov/prod/2005pubs/censr-26.pdf [accessed

Harvey, David I July 20I3]

I989 The Condition of Postmodernity: An Enquiry into the Origins of Cultural Change. Oxford: Blackwell.

Hayes, Geoffrey, and Michael J Levin

I983 A Statistical Profile of Samoans in the United States. Evidence from 
the I980 Census. Washington, DC: US Department of Labor Employ-

Henderson, April K ment and Training Administration.

20I I Fleeting Substantiality: The Samoan Giant in US Popular Discourse. The Contemporary Pacific 23:269-302.

James, C L R

I993 Beyond a Boundary. Durham, NC: Duke University Press. First published in 1963 by Hutchinson \& Co.

Janes, Craig R

I990 Migration, Social Change and Health: A Samoan Community in Urban California. Stanford: Stanford University Press.

Johnston, Richard W

I976 Shake 'em Out of the Coconut Trees. Sports Illustrated, I 6 August. http://si.com/vault/article/magazine/MAG I09 I 426/index.htm [accessed I7 Jan 20I4]

Lilomaiava-Doktor, Sa'iliemanu

2009 Beyond "Migration": Samoan Population Movement (Malaga) and the Geography of Social Space (Vā). The Contemporary Pacific 2I:I-32.

LiPuma, Edward

I993 Culture and the Concept of Culture in a Theory of Practice. In Bourdieu: Critical Perspectives, edited by Craig Calhoun, Edward LiPuma, and Moishe Postone, I4-34. Chicago: University of Chicago Press.

Maguire, Joseph

I999 Global Sport: Identities, Societies, Civilizations. Malden, MA: Blackwell.

Markham, Jesse Makani

2008 An Evolving Geography of Sport: The Recruitment and Mobility of Samoan College Football Players I998-2006. MA thesis in geogra-

Merry, Sally Engle phy, University of Hawai'i at Mānoa.

2000 Colonizing Hawai'i: The Cultural Power of Law. Princeton, NJ: Princeton University Press.

Miller, Toby, Geoffrey A Lawrence, Jim McKay, and David Rowe

I999 Modifying the Sign: Sport and Globalization. Social Text I 7: I 5-33.

Pelley, Scott, director

20I0 American Samoa: Football Island. Episode of 60 Minutes, Свs. I4 January.

Sassen, Saskia

I998 Globalization and Its Discontents: Essays on the New Mobility of People and Money. New York: New Press. 
Spear, Jeremy, and Robert Pennington, directors

2005 Polynesian Power: Islanders in Pro Football. Documentary film. Honolulu: Pacific Islanders in Communications.

Tanier, Mike

2010 Excess Reigns at Super Bowl and That's No Ballyhoo. New York Times, 30 January. http://www.nytimes.com/2010/oI/3 I/sports/ football/3 I hype.html?pagewanted=all\&_r=o [accessed I 4 Jan 20I 4 ]

Taylor, Rachel Kahn, director

2010 Warriors Born: American Samoans in the U.S. Military. Documentary film. Online at http://rachelkahntaylor.com/videos.html.

Teaiwa, Teresia

I995 Scholarship from a Lazy Native. In Work in Flux, edited by Emma Greenwood, Andrew Sartori, and Klaus Neumann. 58-72. Melbourne: Melbourne University Press.

Tengan, Ty P Kāwika, and Jesse Makani Markham

2009 Performing Polynesian Masculinities in American Football: From "Rainbows to Warriors." The International Journal of the History

Torre, Pablo O of Sport 26 (I6): 24I 2-243I.

2009 How (and Why) Athletes Go Broke. Sports Illustrated, 23 March. http://sportsillustrated.cnn.com/vault/article/magazine/MAGII53364 [accessed I4 Jan 20I4]

Uperesa, Fa'anofo Lisaclaire

2010 Fabled Futures: Development, Gridiron Football, and Transnational Movements in American Samoa. PhD dissertation in anthropology, Columbia University.

Forthcoming Seeking New Fields of Labor: Football and Colonial Political Economies in American Samoa. In Formations of US Colonialism, edited by Alyosha Goldstein. Durham, nc: Duke University Press.

US Department of Labor

2007 Economic Report: The Minimum Wage in American Samoa, 2007. May. Washington, DC: US Department of Labor, Employment Standards Administration, Wage and Hour Division. http://www.dol.gov/ whd/AS/EconomicReport-2007.pdf [accessed I 4 Jan 20I4]

Vogan, Travis

2014 Keepers of the Flame: NFL Films and the Rise of Sports Media. Champaign: University of Illinois Press.

Watterson, John Sayle

2000 College Football: History, Spectacle, Controversy. Baltimore: Johns Hopkins University Press. 


\section{Abstract}

Since the I970s, Samoan participation in American gridiron football has grown exponentially. In American Sāmoa (and other transpacific Samoan communities), football has come to represent both a real and imagined "way out" of what appears to many as a strangled field of possibility. The visibility and vibrancy of football in American Sāmoa is rooted in Samoan histories of migration to the United States, Samoan cultural sensibilities, the changing market of the American football industry, and narrowing economic opportunities. The transnational nature of football migration is key to understanding the appeal of playing football, the rewards that accrue to successful players, and how these resources have continued to transform conditions of possibility (materially and ideologically) for young people in the islands. This article explores the layered and complex motivations for football participation as shaped by prospective forms of capital, transnational sporting institutions, and historical contingency. Focused on history, economy, and a transformed vision of the future, it offers a critical genealogy of football in (American) Sāmoa and Samoans in football.

KEYWORDS: American Sāmoa, football, migration, mobility, capital 